\title{
Mineral composition of raw and marinated-cooked arms from Pacific giant squid (Dosidicus gigas)
}

\author{
Faustina Fernández, Celia Lucas, Sancho Bañón* \\ Department of Food Science and Technology and Nutrition, Faculty of Veterinary Science, University of Murcia, Murcia, 30100, Spain
}

\section{A B S T R A C T}

\begin{abstract}
Background/aim: Shellfish consumption is often perceived as a potential health hazard due to the accumulation of toxic metals. The mineral content was investigated in marinated-cooked giant squid (Dosidicus gigas) arms from three Eastern Pacific fisheries (Peru, Chile and Benthic) to elucidate their contribution to daily recommended intakes and possible presence of pollutants. Material and methods: Thirty macro- and microminerals were analysed in the raw material, marination solution, cooking broth and cooked product. Results: Both raw and marinated-cooked squid arms contained nutritionally relevant quantities of essential macro- ( $\mathrm{Na}$ and $\mathrm{Mg}$ ) and microminerals (Cr, $\mathrm{Zn}$, Mn and Se). Fishery origin led to minor variations in the mineral composition of raw arms, while marinated-cooked arms of Benthic origin had a higher retention of $\mathrm{Na}$ and juice likely due to their greater size. Levels of $\mathrm{Pb}, \mathrm{Hg}, \mathrm{Zn}$ or As found in the ready-to-eat product were below tolerable upper intake levels. Conclusion: The mineral content found in the raw squid arms suggests that the Pacific fisheries concerned are not affected by human polluting activities. Marinated-cooked squid arms cover a part of the dietary requirements for minerals and can be consumed without apparent negative nutritional implications.
\end{abstract}

Keywords: Dosidicus gigas; Cooked squid; Heavy metals; Minerals; Shellfish

\section{INTRODUCTION}

Cephalopods are considered an excellent source of highquality nutrients (proteins, n-3 polyunsaturated lipids, essential minerals, etc.); however, there is a growing belief that shellfish may come from increasingly polluted waters, therefore their consumption is often perceived as a potential health-hazard (Catsiki and Strogyloudi, 1999; Llobet et al., 2003; Leblanc et al., 2005). Knowledge of toxic metal accumulation in shellfish from different fisheries around the world contributes to this opinion. Indeed, several surveys have warned of the tendency for cephalopods to accumulate toxic heavy metals, such as $\mathrm{Hg}, \mathrm{Cd}$ and $\mathrm{Pb}$ (Storelli et al., 2005; Perelló et al., 2008; Storelli et al., 2012). These three heavy metals have no known role in biological systems and may be toxic even at low concentrations when ingested over a long period (Carvalho et al., 2005; Domingo et al., 2006). Exposure to high levels of $\mathrm{Hg}$ can damage the brain, kidneys and developing foetus (Azlan et al., 2012), Cd is primarily toxic to the kidney, can cause bone demineralisation and has been classified as potentially carcinogenic (Jaishankar et al., 2014), while exposure to Pb can cause kidney dysfunction and brain damage, among other health problems (Förstner and Wittmann, 1981). In addition, cephalopods may accumulate other trace elements responsible for other health disorders, such as As (Jiao et al., 2018), a prominently toxic and carcinogenic agent (Storelli, et al., 2005; Domingo, et al., 2006), whose longterm exposure can lead to the formation of skin lesions, internal cancers, neurological problems, pulmonary disease, peripheral vascular disease, hypertension and cardiovascular disease and diabetes mellitus (Smith et al., 2000).

Mineral accumulation in cephalopods depends on animal traits (species, variety, body size, age, specific tissues and organs) and environmental factors affecting their diet, in particular, water pollution in the fishery (Duysak and Uğurlu, 2017). In this respect, many coastal waters are increasingly polluted by the discharge of industrial waste (Castro-González and Méndez-Armenta, 2008; Azlan et al., 2012). The main sources of the heavy metals accumulated in cephalopods are anthropogenic activities (smelting processes, fuel combustion, etc.) in the zones where they are captured (Ayas et al., 2007; Mendil and Uluözlü, 2007). Cephalopods can grow and reproduce in polluted environments containing toxic metals, which are

\footnotetext{
${ }^{*}$ Corresponding author:

Sancho Bañón, Department of Food Science and Technology and Nutrition, Faculty of Veterinary Science, University of Murcia, Murcia, 30100, Spain
} 
gradually absorbed, metabolized and accumulated (Younis et al., 2015). When different tissues (muscles, liver and gills) affected by metal bioaccumulation were examined for risk assessment purposes, the marine animals closely related with sediments, such as squid, showed a relatively high accumulation of heavy metals, for therefore are considered as good indicators in the long-term monitoring of metal pollution in the marine environment (Kilgour, 1991; Agusa et al., 2007; Vilizzi and Tarkan, 2016).

In the case of giant squid (Dosidicus gigas), shellfish factories located in developed countries are increasingly dependent on raw materials from Pacific fisheries (Tores-Arreola et al., 2018), and the seafood industry is interested in knowing the nutritional implications of the consumption of squid-based products. However, most available studies on the accumulation levels and dietary intake of trace elements through seafood consumption focus on whole animals (Domingo et al., 2006) and therefore, do not provide an exact idea of the minerals contained in readyto-eat products. The mineral content can vary during shellfish processing; for example, evisceration removes the minerals deposited in the liver and other organs, while other treatments applied to the edible parts may favour mineral exchange through exudates, marination solutions or cooking broths. In addition, juice losses by cooking may concentrate the minerals initially present in the raw materials (Kalogeropoulos et al., 2012; Czech and Stachyra, 2013). Therefore, it was of interest to learn the mineral content of shellfish products to establish their recommended intake levels and to prevent toxicological risks.

The contribution to diet of minerals, including pollutants, referred for raw or cooked whole squid cannot be extrapolated to ready-to-eat industrial products based on muscle treated with mineral solutions. The objective of the present work was to study the mineral profile of a marinated-cooked giant squid arm from a dietary (recommended daily intakes) and health point of view (toxic heavy metals). Changes in mineral concentrations were assessed in raw and final products from three different Pacific squid fisheries.

\section{MATERIALS AND METHODS}

\section{Experimental design and statistical analysis}

A randomized factorial design was performed to study the influence of fishery origin on the mineral content of cooked squid cuts. Three samples from eighteen blocks of frozen arms were analysed in triplicate (3 blocks x 3 fishery origins $x 3$ fishing seasons). The effect of treatments (fishery origin and processing) on the dependent variables (proximate composition and mineral content) was determined by one-way variance analysis. A Tukey homogeneity test was used to compare the Lean Square Means, which were considered to be statistically different at $\mathrm{P}<0.05$. Statistical analysis was carried out using the Statistics 8.0 for Windows (Analytical Software, Tallahassee, Florida, USA).

\section{Squid fishing and obtaining arm block}

Giant squid were caught using fishing hooks and lines in three different zones from the Central-Eastern Pacific Ocean (Chile, Peru and Benthic) (Food and Agriculture Organization FAO fishing zone No. 87) in three different seasons (Table 1). The squid captured on fish factory boats were manually eviscerated, cleaned and cut to separate mantles, fins and arms (edible parts) to obtain the respective blocks of frozen product $\left(-20^{\circ} \mathrm{C}\right.$ for $\left.12-20 \mathrm{~h}\right)$. Blocks of frozen arms were packed in polyethylene bags and placed in raffia containers for transport to the respective storage and distribution centres in Perú, Chile and China (Benthic origin). Some of these blocks were placed in freezing vessels (at $-18{ }^{\circ} \mathrm{C}$ ) and transported from each supplier to a cephalopod products factory located in Spain (New Concisa, Cieza, Murcia). The frozen arm blocks were stored at $-18^{\circ} \mathrm{C}$ for up to $1-2$ months prior to production of the cooked product. Cooking time duration was adjusted to raw squid average size.

\section{Cooked squid arm processing}

The squid arms were cooked following an industrial procedure. The frozen blocks containing arms were thawed at $10{ }^{\circ} \mathrm{C}$ for $24 \mathrm{~h}$ in tanks containing a water solution with $0.05 \mathrm{mg}$ hydrogen peroxide per $\mathrm{kg}$. A water solution containing $13 \mathrm{~g}$ sodium salts per kg (citric acid, sodium citrate, sodium biphosphate and triphosphate) was injected (at $4.5 \mathrm{~atm}$ ) into the thawed arms to correct ammonia off-flavours and to improve juice retention. After one hour, the marinated arms were cooked in two steps: (i) pre-cooking at $65^{\circ} \mathrm{C}$ for $15 \mathrm{~min}$; and (ii) cooking at $98{ }^{\circ} \mathrm{C}$ for $45 \mathrm{~min}$ (Chile), $50 \mathrm{~min}$ (Benthic) or $40 \mathrm{~min}$ (Perú) using a continuous cooking tunnel (Teycomur Maquinaria, Ceutí, Murcia, Spain). A commercial spiced product used for the cooking broth (Doscadesa 2000, Molina de Segura, Murcia, Spain) was diluted in water at $1: 32 \mathrm{w}: \mathrm{w}$ and the solution was added to marinate the arms in the second cooking step. According to the supplier, the ingredients of the spiced product were: sodium chloride, sugar, sodium triphosphate, spices (garlic, savoury and bay), flavouring agents and sodium glutamate. After cooking, the squid arms were cooled in a water tank at $2{ }^{\circ} \mathrm{C}$ for $5 \mathrm{~min}$ until they reached an internal temperature of $25^{\circ} \mathrm{C}$. The arms were longitudinally cut to obtain the whole arms and transversally sliced $(12 \mathrm{~mm})$ in an automatic cutting machine. Squid cuts were then passed into a spiral freezing 
Table 1: Time course for obtaining cooked giant squid arms

\begin{tabular}{lccc} 
& & Fishery origin & Peru \\
\cline { 2 - 4 } & Chile & Benthic & $0.5-1 \mathrm{~kg}$ \\
Whole arms (8) weight range & $1-2 \mathrm{~kg}$ & $2-3 \mathrm{~kg}$ & $0.610 \mathrm{~kg}$ \\
Whole arms (8) average weight & $1.850 \mathrm{~kg}$ & $2.200 \mathrm{~kg}$ & Fresh \\
FAO area coordinates & $87.2 .2-25.220000,71.397112$ & $87.2 .5-26.168045,105.926169$ & $87.1 .2-15.373938,-76800431$ \\
Transportation in board to freezer & Fresh & Frozen & $09.2017-05.2018$ \\
Capture and freezing date & $06.2017-07.2018$ & $03.2017-03.2018$ & $01.2018-11.2018$ \\
Blocks reception date & $01.2018-10.2018$ & $01.2018-10.2018$ & $03.2018-12.2018$ \\
Arms processing date & $02.2018-12.2018$ & $02.2018-12.2018$ & \\
\hline
\end{tabular}

tunnel with air convection at $-25{ }^{\circ} \mathrm{C}$ for 40 min. Finally, squid cuts were glassed with cold water and aerobically packed into polyethylene - polypropylene bags to obtain the final product. The concentrations of the macro- and microminerals present in the marination solution and cooking broth used in raw arm processing are shown in Table 2 (see analytical procedure in 2.5 subsection).

\section{Proximate composition}

Moisture $(\mathrm{g} / 100)$ was determined after dehydration at 105 'C (International Standard Organization "ISO" Norm 1442: 1997) using a D6450 drying oven (Heraeus, Boadilla del Monte, Madrid, Spain) and a BP $110 \mathrm{~S}$ (0.001 g precision) scale (Sartorius, Alcobendas, Madrid, Spain). Total lipids (g/100) were determined by the Soxhlet extraction procedure (ISO Norm 1443: 1973) using a 4002841 Det-Grass extraction unit (Selecta, Barcelona Spain) and petroleum ether as solvent. Total nitrogen ( $\mathrm{g} / 100$ ) was determined following the Kjeldhal method as specified by ISO Norm 937 (1978) using a K-435 digestion unit (Büchi Labortechnik, Flawil, Switzerland) and a KT 200 Kjeltec distillation unit (Foss, Barcelona, Spain). Ammonia was titrated using an automatic Titrino 702 SM instrument equipped with a No. 6.0233.100 combined electrode (Methrom Schweiz, Zofingen, Switzerland). The factor 6.25 was used to convert nitrogen into protein. The ash content $(\mathrm{g} / 100)$ was determined according to ISO Norm 936 (1998) using an HK-11 muffle furnace (Forns Hobersal, Caldes de Montbui, Barcelona, Spain).

\section{Macro- and microminerals}

Samples were prepared according to the United States Environmental Protection Agency Method 3015 "A microwave assisted acid digestion of aqueous samples and extracts". Macro- and microminerals were determined according to ISO Norm 11.885 (1996) by Inductively Coupled Plasma Optical Emission Spectrometry (ICPOES) using a Thermo ICAP 6500 Duo apparatus (Thermo Fisher Scientific, Waltham, Massachusetts, USA), except for $\mathrm{Hg}$, which was determined using a mass spectrometry detector (ICP-MS Agilent 7900). A multimineral standard solution containing thirty-one minerals supplied by SCP Science (Quebec, Canada) was used to prepare
Table 2: Concentration of macro- and microminerals found in the certified reference material and food enriched samples

\begin{tabular}{|c|c|c|c|c|}
\hline & \multicolumn{2}{|c|}{$1577 c^{1}$} & \multicolumn{2}{|c|}{ Recovery \% } \\
\hline & Certified & Measured & $1577 c^{1}$ & Food samples ${ }^{2}$ \\
\hline $\mathrm{Al}$ & & & & 95.4 \\
\hline As & $19.6 \pm 1.40$ & $19.2 \pm 3.14$ & 98.0 & 105.6 \\
\hline B & & & & 103.5 \\
\hline $\mathrm{Be}$ & & & & 108.9 \\
\hline $\mathrm{Bi}$ & & & & 105.5 \\
\hline $\mathrm{Ca}$ & $131.0 \pm 10.0$ & $127.5 \pm 10.3$ & 97.3 & 94.3 \\
\hline $\mathrm{Cd}$ & $97.0 \pm 1.40$ & $95.8 \pm 0.78$ & 98.8 & 95.3 \\
\hline Co & $0.3 \pm 0.02$ & $0.3 \pm 0.03$ & 99.0 & 106.0 \\
\hline $\mathrm{Cr}$ & $53.0 \pm 14.0$ & $51.8 \pm 16.2$ & 97.7 & 94.3 \\
\hline $\mathrm{Cu}$ & $275.2 \pm 4.60$ & $269.7 \pm 2.80$ & 98.0 & 97.0 \\
\hline $\mathrm{Fe}$ & $197.9 \pm 0.65$ & $205.5 \pm 7.83$ & 103.8 & 103.9 \\
\hline $\mathrm{Hg}$ & $5.4 \pm 0.17$ & $5.2 \pm 0.65$ & 97.0 & 93.6 \\
\hline K & $1.0 \pm 0.06$ & $1.0 \pm 0.01$ & 98.4 & 94.6 \\
\hline $\mathrm{La}$ & & & & 106.5 \\
\hline $\mathrm{Li}$ & & & & 106.8 \\
\hline $\mathrm{Mg}$ & $620.0 \pm 42.0$ & $636.1 \pm 8.25$ & 102.6 & 94.7 \\
\hline $\mathrm{Mn}$ & $10.5 \pm 0.47$ & $11.4 \pm 0.23$ & 109.2 & 96.2 \\
\hline Mo & $3.3 \pm 0.13$ & $3.3 \pm 0.14$ & 101.0 & 106.1 \\
\hline $\mathrm{Na}$ & $0.2 \pm 0.01$ & $0.2 \pm 0.00$ & 98.4 & 95.2 \\
\hline $\mathrm{Ni}$ & $44.5 \pm 9.20$ & $43.3 \pm 9.01$ & 97.4 & 94.8 \\
\hline $\mathrm{Pb}$ & $62.8 \pm 1.00$ & $61.8 \pm 7.79$ & 98.5 & 96.4 \\
\hline $\mathrm{Rb}$ & $35.3 \pm 1.10$ & $35.8 \pm 2.37$ & 101.3 & 105.4 \\
\hline $\mathrm{Sb}$ & $3.1 \pm 0.31$ & $3.2 \pm 0.00$ & 103.7 & 107.6 \\
\hline $\mathrm{Se}$ & $2.0 \pm 0.05$ & $2.0 \pm 0.08$ & 100.4 & 106.4 \\
\hline Si & & & & 105.3 \\
\hline $\mathrm{Sr}$ & $95.3 \pm 4.20$ & $92.5 \pm 2.80$ & 97.1 & 97.0 \\
\hline $\mathrm{Ti}$ & & & & 108.1 \\
\hline $\mathrm{TI}$ & & & & 107.1 \\
\hline V & $8.2 \pm 0.66$ & $8.6 \pm 2.59$ & 105.7 & 96.8 \\
\hline $\mathrm{Zn}$ & $181.1 \pm 1.00$ & $177.1 \pm 3.55$ & 97.8 & 105.0 \\
\hline
\end{tabular}

${ }^{1}$ Certified or reference $(\mathrm{Sb}$ and $\mathrm{Hg}$ ) values for the Standard Reference Material 1577c (Bovine Liver) (National Institute of Standards \&

Technology, USA) ( $n=3) .{ }^{2}$ Average values determined in food samples (orange juice, lettuce, milk powder and pot based on meat andvegetables) enriched with a multimineral standard solution (SCP Science, Quebec, Canada) $(n=3)$. All the concentrations are expressed as $\mathrm{g} / 100 \mathrm{~g}(\mathrm{Na}$ and $\mathrm{K})$ and $\mathrm{mg} / \mathrm{kg}$ (rest of minerals). Detection limits (LoD): $25 \mathrm{mg} / \mathrm{kg}$ ( $\mathrm{Na}, \mathrm{K}, \mathrm{Mg}$, $\mathrm{Ca}$ and $\mathrm{Si}$ ) and $0.25 \mu \mathrm{g} / \mathrm{kg}$ (rest of minerals). Quantification limits (LoQ): $0.01 \mathrm{~g} / 100 \mathrm{~g}(\mathrm{Na}, \mathrm{K}, \mathrm{Mg}, \mathrm{Ca}$ and $\mathrm{Si}$ ) and $0.001 \mathrm{mg} / \mathrm{kg}$ (rest of minerals)

calibration standards in ultrapure water. For the ICP analyses, two control samples containing ultrapure water and a multimineral standard were used. Each mineral determination was performed at specific wavelengths 
ranging from 167.1 to $670.8 \mathrm{~nm}$. The sample concentrations of macro- $(\mathrm{g} / 100 \mathrm{~g})$ and micro $(\mathrm{mg} / \mathrm{kg})$ minerals were calculated as follows.

$$
C=\frac{S \times D}{W}
$$

where $C$ was the content of macro- (g/100g w.w.) and micro (mg/kg w.w.) minerals in the squid sample, $\mathrm{S}$ was the mineral concentration of the working solution, D was the dilution factor and W was sample weight. A Standard Reference Material 1577c (Bovine Liver; National Institute of Standards \& Technology, USA) was used for method validation. In addition, the method was validated for food samples (orange juice, lettuce, milk powder and pot based on meat and vegetables) added with the multimineral standard solution. All the mineral determinations had suitable values of linearity $\left(r^{2} \geq 0.99\right)$, repeatability $( \pm 10 \%)$ and recovery percentages ranging 94.6-108.9\% (see table 2).

\section{Calculation of Dietary Reference Intakes.}

Dietary Reference Intakes (DRIs) were calculated according to the guidelines published by the European Food Safety Agency (EFSA) (2006 and 2017) for an adult person (older than 19 years) with no special nutritional requirements, averaging male and female requirements. The references used were: (i) Population Reference Intake (PRI): the level of (nutrient) intake that is adequate for virtually all people in a population group. This meets the requirements of 97.5\% of individuals in the population; (ii) Adequate Intake (AI): the average observed or experimentally determined approximations or estimates of nutrient intake by a population group (or groups) of apparently healthy people that is assumed to be adequate. It is the value estimated when a PRI cannot be established; (iii) Tolerable Upper Intake Level (UL): the maximum level of total chronic daily intake of a nutrient (from all sources) judged unlikely to pose a risk of adverse health effects to humans.

Estimation of Weekly Intake and Target Hazard Quotient for toxic heavy metals.

The Estimated Weekly Intake (EWI) $(\mu \mathrm{g} / \mathrm{kg}$ b.w.) for the toxic metals $\mathrm{Pb}, \mathrm{Cd}$ and $\mathrm{Hg}$ through the consumption of cooked squid was calculated as follows:

$$
\mathrm{EWI}=\frac{\mathrm{C} \times \mathrm{FIR} \times 7}{\mathrm{WAB}}
$$

where EWI is the Estimated Weekly Intake in $\mu \mathrm{g} / \mathrm{kg}$ b.w., $\mathrm{C}$ is the metal concentration in seafood ( $\mu \mathrm{g} / \mathrm{g}$ w.w.); FIR is the Food Ingestion Rate for cephalopods ( 9.8 g per person and day); 7; provides the expression of results of a weekly basis; and WAB is the average consumer body weight (60 kg) according to the European Union (EU) Scientific Committee for Food Adult Weight (Kalogeropoulos et al. 2012).

The Probable Tolerable Weekly Intake (PTWI) used as reference for $\mathrm{Cd}, \mathrm{Hg}$ and $\mathrm{Pb}$ were respectively 2.5, 7 and 25 $\mu \mathrm{g}$ per kg body wt and wk (European Food Safety Authority "EFSA", 2011; World health organization "WHO", 2003).

\section{RESULTS}

\section{Proximate composition}

The proximate composition of raw and cooked squid arms is shown in Table 3. In general, the moisture content decreased from $83.0 \mathrm{~g} / 100 \mathrm{~g}$ (raw material) to 75.1 (cooked product), total protein content strongly increased from 13.0 (raw) to $20.8 \mathrm{~g} / 100 \mathrm{~g}$ (cooked), the total lipid content was similar in the raw and cooked product (around $2.1 \mathrm{~g} / 100 \mathrm{~g}$ ), while the ash content increased from $1.2 \mathrm{~g} / 100 \mathrm{~g}$ (raw) to $1.8 \mathrm{~g} / 100 \mathrm{~g}$ (cooked). A further analysis confirmed that the cooking spices used (including glutamate and flavouring agents) contained $0.3 \mathrm{~g}$ nitrogen per $100 \mathrm{~g}$ product, of which a part could have passed to the cooked squid. Fishery origin produced some compositional differences in squid arm. As regards the raw material, Benthic samples (large size) had the highest moisture content followed by the Peru (small size) and Chile (medium size) samples, while the lipid content was higher in the Peru than in the Chile samples. After cooking, the Peru samples had the lowest moisture and ash contents, while the Benthic samples had the highest ash content. Apart from these differences among fishery origins as regards the content of lipids and proteins, other possible factors that may affect mineral diffusion and/or

\begin{tabular}{|c|c|c|c|c|c|}
\hline & Chile & Benthic & Peru & Overall & SEM \\
\hline & M & M & M & M & \\
\hline \multicolumn{6}{|l|}{ Raw arms } \\
\hline Moisture & $82.01^{c}$ & $83.76^{a}$ & $83.10^{b}$ & 82.96 & 0.27 \\
\hline $\begin{array}{l}\text { Total } \\
\text { proteins }\end{array}$ & 12.75 & 12.67 & 13.04 & 13.02 & 0.25 \\
\hline Total lipids & $2.19^{b}$ & $2.29^{a b}$ & $2.63^{a}$ & 2.37 & 0.08 \\
\hline Ash & 1.25 & 1.15 & 1.08 & 1.16 & 0.06 \\
\hline \multicolumn{6}{|l|}{ Cooked arms } \\
\hline Moisture & $75.45^{a}$ & $76.19^{a}$ & $73.78^{b}$ & 75.13 & 0.30 \\
\hline $\begin{array}{l}\text { Total } \\
\text { proteins }\end{array}$ & 20.77 & 20.23 & 21.54 & 20.85 & 0.25 \\
\hline Total lipids & 2.04 & 2.21 & 2.33 & 2.20 & 0.06 \\
\hline Ash & $1.77^{\mathrm{ab}}$ & $2.16^{a}$ & $1.59^{b}$ & 1.84 & 0.08 \\
\hline
\end{tabular}
juice losses, were of no importance.

M: mean; SEM: Standard error of the mean; Means with different superscripts are different for ${ }^{*} \mathrm{P}<0.05$ 


\section{Mineral content}

Most of the analysed macro- and microminerals, particularly $\mathrm{Na}$, were already present at different concentrations in the additives and media used for squid arm processing (see Table 4). The average contents of macro- and microminerals in raw and cooked squid arms are shown in Table 5. In the raw material, the most abundant macrominerals $(\mathrm{g} / 100 \mathrm{~g})$ were $\mathrm{K}(0.22), \mathrm{Na}(0.15), \mathrm{Mg}(0.03)$ and $\mathrm{Ca}(0.01)$, with the Chile samples having the highest concentrations of $\mathrm{K}$ and $\mathrm{Na}$. The most abundant microminerals $(\mathrm{mg} / \mathrm{kg})$ were $\mathrm{Zn}$ (13.7), Si (4.6), Mn (2.6), Cu (2.6), Sr (1.3) and Fe (1.1), while the rest had concentrations below $1 \mathrm{mg} / \mathrm{kg}$. The concentration of microminerals was similar in the raw arms from the three fisheries, except for As and B, whose levels were higher in Peru samples than Benthic ones. Concerning the cooked product, the most abundant macrominerals were $\mathrm{Na}(0.37), \mathrm{K}(0.10), \mathrm{Mg}$ (0.07) and $\mathrm{Ca}$ (0.03), with Benthic samples having higher $\mathrm{Na}$ concentrations than the Chile samples. The most abundant microminerals were $\mathrm{Si}$ (23.2) and $\mathrm{Zn}$ (21.4), followed by Sr (6.5), Cu (3.0), Mn (2.8), $\mathrm{Fe}(2.5)$ and $\mathrm{Al}$ (1.5). As in the case of the raw material,

\begin{tabular}{|c|c|c|c|c|}
\hline & \multicolumn{2}{|c|}{ Marination solution } & \multicolumn{2}{|c|}{ Cooking broth } \\
\hline & M & SEM & M & SEM \\
\hline Al & $<0.10$ & & 0.43 & 0.15 \\
\hline As & $<0.01$ & & $<0.01$ & \\
\hline B & 0.69 & 0.02 & 0.12 & 0.02 \\
\hline $\mathrm{Be}$ & $<0.01$ & & $<0.01$ & \\
\hline $\mathrm{Bi}$ & $<0.01$ & & $<0.01$ & \\
\hline $\mathrm{Ca}$ & 70.52 & 2.62 & 91.64 & 0.28 \\
\hline $\mathrm{Cd}$ & $<0.01$ & & $<0.01$ & \\
\hline Co & $<0.01$ & & $<0.01$ & \\
\hline $\mathrm{Cr}$ & 0.07 & 0.00 & 0.03 & 0.01 \\
\hline $\mathrm{Cu}$ & 0.13 & 0.00 & 0.05 & 0.00 \\
\hline $\mathrm{Fe}$ & $<0.10$ & & 0.32 & 0.12 \\
\hline $\mathrm{Hg}$ & $<0.01$ & & $<0.01$ & \\
\hline K & 217.61 & 8.51 & 24.94 & 2.71 \\
\hline $\mathrm{La}$ & $<0.01$ & & $<0.01$ & \\
\hline Li & 0.26 & 0.01 & 0.04 & 0.00 \\
\hline $\mathrm{Mg}$ & 162.88 & 1.74 & 35.61 & 0.36 \\
\hline $\mathrm{Mn}$ & 0.41 & 0.01 & 0.23 & 0.01 \\
\hline Mo & $<0.01$ & & $<0.01$ & \\
\hline $\mathrm{Na}$ & $3.1610^{4}$ & $0.1510^{4}$ & $0.5610^{4}$ & $0.0910^{4}$ \\
\hline $\mathrm{Ni}$ & 0.01 & 0.00 & 0.03 & 0.01 \\
\hline $\mathrm{Pb}$ & $<0.01$ & & $<0.01$ & \\
\hline $\mathrm{Rb}$ & 0.32 & 0.00 & 0.03 & 0.00 \\
\hline $\mathrm{Sb}$ & $<0.01$ & & $<0.01$ & \\
\hline Se & $<0.01$ & & $<0.01$ & \\
\hline $\mathrm{Si}$ & 1.98 & 0.05 & 12.58 & 3.52 \\
\hline $\mathrm{Sr}$ & 1.93 & 0.04 & 1.74 & 0.02 \\
\hline $\mathrm{Ti}$ & 0.03 & 0.00 & 0.05 & 0.01 \\
\hline TI & $<0.01$ & & $<0.01$ & \\
\hline V & $<0.01$ & & $<0.01$ & \\
\hline $\mathrm{Zn}$ & 0.05 & 0.00 & 0.06 & 0.02 \\
\hline
\end{tabular}

the cooked product contained levels below $1 \mathrm{mg} / \mathrm{kg}$ for the rest of the microminerals, including toxic heavy metals such as $\mathrm{Pb}, \mathrm{Hg}$ and $\mathrm{Cd}$, with no differences among fishery origins, except for Cd (higher in Peru) and $\mathrm{Cr}$ (higher in Chile). Concentrations of macro- and microminerals increased $(\mathrm{P}<0.05)$ in the cooked product, with some exceptions: the levels of $\mathrm{K}$ were lower $(\mathrm{P}<0.05)$ in the cooked samples, while the levels of $\mathrm{Cr}, \mathrm{Cu}, \mathrm{Mn}$ and $\mathrm{Mo}$ were similar $(\mathrm{P}>0.05)$. Thus, fishery origin hardly affected the mineral composition of the raw or cooked product, except for the sodium content.

\section{Dietary intake and consumer risk}

The consumption of $100 \mathrm{~g}$ of cooked product covered a relevant part of the DRI established for $\mathrm{Na}(16.1 \%)$, $\mathrm{Mg}(10.6 \%)$, and, to a lesser extent, for K (2.2\%), while its contribution of $\mathrm{Ca}$ was insignificant $(0.3 \%)$. The consumption of cooked squid also covered a considerable percentage of the DRI for Cr $(26.7 \%), \mathrm{Zn}(21.4 \%)$, Mn $(13.7 \%)$ and Se $(12.0 \%)$, while this contribution of other minerals were minor. In addition, the EWI and PTWI for $\mathrm{Hg}, \mathrm{Cd}$ and $\mathrm{Pb}$ for the consumption of cooked squid were also calculated. The EWI ( $\mu \mathrm{g} / \mathrm{g}$ w.w.) (PTWI in bracket) for Hg were: Chile: 0.06 (12\%); Benthic: 0.06 (12\%); Peru: 0.04 (8\%); and overall: 0.05 (10\%). The EWI (PTWI in bracket) for $\mathrm{Cd}$, the most abundant of these three heavy metals, were Chile: 0.06 (2.4\%); Benthic: 0.16 (6.4\%); Peru: 0.06 (2.4\%); and overall: 0.09 (4\%). Finally, the EWI (PTWI in bracket) for $\mathrm{Pb}$ were particularly low: Chile: 0.01 (0.04\%); Benthic: 0.01 (0.04\%); Peru: 0.02 (0.08\%); and overall: 0.01 $(0.05 \%)$. As for metal content, there were no differences among origins in EWI and PTWI, except in the case of the Benthic samples, which provided double $\mathrm{Cd}$ intake than the other two origins.

\section{DISCUSSION}

There are few available studies regarding the mineral content of cooked squid products, and most existing information corresponds to pollution studies on toxic metals in whole squid. The present study focuses on a ready-to eat squid product in which the minerals (semiand metals) of nutritional and toxicological interest were studied in the raw material, processing solutions and final product. Regarding the raw material, the mineral content of giant squid arm was coherent with those reported in other studies. Recently, Jiao et al. (2018) determined several trace metals in muscle samples (all edible parts) of Chinese (Loligo chinesis), Pacific (Ommastrephes bartramii and Dosidicus gigas) and Atlantic (Illex argentines) raw squid. As in this study, the above authors found considerable differences according to the body weight of squid from different fisheries; the average contents $(\mathrm{mg} / \mathrm{kg})$ reported were: $\mathrm{Zn}$ 
Table 5: Average content of macro- $(\mathrm{g} / 100 \mathrm{~g})$ and microminerals $(\mathrm{mg} / \mathrm{kg})$ in raw and cooked giant squid arms from three Pacific fisheries

\begin{tabular}{|c|c|c|c|c|c|c|c|c|c|c|}
\hline & \multicolumn{5}{|c|}{ Raw arms } & \multicolumn{5}{|c|}{ Cooked arms } \\
\hline & Chile & Benthic & Peru & Overall & & Chile & Benthic & Peru & Overall & SEM \\
\hline & M & M & M & M & SEM & M & M & M & M & \\
\hline \multicolumn{11}{|c|}{ Macrominerals } \\
\hline $\mathrm{Ca}$ & 0.01 & 0.01 & 0.01 & 0.01 & 0.00 & 0.03 & 0.03 & 0.03 & 0.03 & 0.01 \\
\hline $\mathrm{K}$ & $0.26^{\mathrm{a}}$ & $0.19^{a}$ & $0.22^{\mathrm{ab}}$ & 0.22 & 0.01 & 0.11 & 0.11 & 0.09 & 0.10 & 0.02 \\
\hline $\mathrm{Mg}$ & 0.03 & 0.03 & 0.03 & 0.03 & 0.00 & 0.06 & 0.08 & 0.06 & 0.07 & 0.01 \\
\hline $\mathrm{Na}$ & $0.16^{\mathrm{a}}$ & $0.15^{\mathrm{ab}}$ & $0.13^{\mathrm{b}}$ & 0.15 & 0.01 & $0.33^{b}$ & $0.49^{\mathrm{a}}$ & $0.29^{a}$ & 0.37 & 0.06 \\
\hline \multicolumn{11}{|c|}{ Microminerals } \\
\hline $\mathrm{Al}$ & 1.17 & 0.14 & 0.39 & 0.57 & 0.29 & 1.21 & 2.57 & 0.73 & 1.51 & 0.99 \\
\hline As & $0.48^{\mathrm{ab}}$ & $0.40^{\mathrm{b}}$ & $0.56^{a}$ & 0.48 & 0.03 & 0.77 & 0.99 & 0.68 & 0.81 & 0.14 \\
\hline B & $<0.01$ & 0.01 & 0.08 & 0.03 & 0.02 & 0.36 & 0.47 & 0.47 & 0.44 & 0.12 \\
\hline $\mathrm{Be}$ & $<0.01$ & $<0.01$ & $<0.01$ & $<0.01$ & & $<0.01$ & $<0.01$ & $<0.01$ & $<0.01$ & \\
\hline $\mathrm{Bi}$ & $<0.01$ & $<0.01$ & $<0.01$ & $<0.01$ & & $<0.01$ & $<0.01$ & $<0.01$ & $<0.01$ & \\
\hline $\mathrm{Cd}$ & 0.02 & 0.02 & 0.04 & 0.02 & 0.00 & $0.05^{b}$ & $0.14^{a}$ & $0.05^{\mathrm{ab}}$ & 0.09 & 0.04 \\
\hline Co & $<0.01$ & $<0.01$ & $<0.01$ & $<0.01$ & & $<0.01$ & $<0.01$ & $<0.01$ & $<0.01$ & \\
\hline $\mathrm{Cr}$ & 0.03 & 0.02 & 0.04 & 0.03 & 0.01 & $0.11^{\mathrm{a}}$ & $0.07^{\mathrm{ab}}$ & $0.06^{b}$ & 0.08 & 0.02 \\
\hline $\mathrm{Cu}$ & 2.64 & 2.15 & 3.09 & 2.63 & 0.30 & 3.35 & 3.13 & 2.4 & 2.96 & 0.64 \\
\hline $\mathrm{Fe}$ & 1.10 & 1.21 & 0.99 & 1.10 & 0.13 & 1.96 & 4.15 & 1.42 & 2.51 & 1.82 \\
\hline $\mathrm{Hg}$ & 0.01 & $<0.01$ & 0.01 & 0.01 & 0.00 & 0.05 & 0.05 & 0.04 & 0.05 & 0.01 \\
\hline $\mathrm{La}$ & $<0.01$ & $<0.01$ & $<0.01$ & $<0.01$ & & $<0.01$ & $<0.01$ & $<0.01$ & $<0.01$ & \\
\hline $\mathrm{Li}$ & $<0.01$ & $<0.01$ & 0.03 & 0.01 & 0.00 & 0.07 & 0.08 & 0.07 & 0.07 & 0.01 \\
\hline $\mathrm{Mn}$ & 2.77 & 2.50 & 2.54 & 2.60 & 0.07 & 2.63 & 3.16 & 2.60 & 2.80 & 0.31 \\
\hline Mo & $<0.01$ & $<0.01$ & 0.07 & 0.02 & 0.02 & 0.01 & $<0.01$ & $<0.01$ & 0.01 & 0.00 \\
\hline $\mathrm{Ni}$ & $<0.01$ & $<0.01$ & $<0.01$ & $<0.01$ & & 0.05 & 0.02 & 0.03 & 0.04 & 0.01 \\
\hline $\mathrm{Pb}$ & 0.02 & 0.02 & 0.02 & 0.02 & 0.00 & 0.01 & 0.01 & 0.02 & 0.01 & 0.00 \\
\hline $\mathrm{Rb}$ & 0.81 & 0.58 & 0.68 & 0.69 & 0.04 & 0.57 & 0.61 & 0.48 & 0.55 & 0.11 \\
\hline $\mathrm{Sb}$ & $<0.01$ & $<0.01$ & $<0.01$ & $<0.01$ & & $<0.01$ & $<0.01$ & $<0.01$ & $<0.01$ & \\
\hline $\mathrm{Se}$ & 0.15 & 0.10 & 0.21 & 0.15 & 0.02 & 0.40 & 0.31 & 0.36 & 0.36 & 0.04 \\
\hline $\mathrm{Si}$ & 3.32 & 4.95 & 5.53 & 4.60 & 1.11 & 14.17 & 14.81 & 40.71 & 23.23 & 17.33 \\
\hline $\mathrm{Sr}$ & 1.31 & 1.27 & 1.27 & 1.28 & 0.04 & 5.75 & 6.81 & 6.84 & 6.47 & 1.45 \\
\hline $\mathrm{Ti}$ & 0.08 & 0.08 & 0.15 & 0.10 & 0.03 & 0.04 & 0.03 & 0.04 & 0.04 & 0.01 \\
\hline TI & $<0.01$ & $<0.01$ & $<0.01$ & $<0.01$ & & 0.03 & 0.03 & 0.03 & 0.03 & 0.01 \\
\hline V & $<0.01$ & $<0.01$ & $<0.01$ & $<0.01$ & & $<0.01$ & $<0.01$ & $<0.01$ & $<0.01$ & \\
\hline $\mathrm{Zn}$ & 14.50 & 13.27 & 13.20 & 13.66 & 0.28 & 22.79 & 19.44 & 22.09 & 21.44 & 3.03 \\
\hline
\end{tabular}

M: mean; SEM: Standard error of the mean; Means with different superscripts are different for ${ }^{*} \mathrm{P}<0.05$

(14.8), Fe (7.9), $\mathrm{Cu}(5.5)$, As (4.8), Mn (0.8), Cr (0.5), Se (0.4), $\mathrm{Cd}(0.3), \mathrm{Pb}(0.08)$ and $\mathrm{Ni}(0.07)$, with giant squid from the Eastern Pacific Ocean having concentrations near these average values. Kalogeropoulos et al. (2012) found more similar levels $(\mathrm{mg} / \mathrm{kg})$ to those of our study for $\mathrm{Zn}$ (9.7), $\mathrm{Fe}$ (6.0), $\mathrm{Cu}(4.7), \mathrm{Cr}(0.06), \mathrm{Cd}(0.3)$ and $\mathrm{Hg}(0.05)$ in raw Mediterranean squid flesh (Loligo vulgaris). Czech and Stachyra (2013) studied a larger number of macro- and microminerals in raw Japanese squid (Todarodes pacificus) samples. As in this study, the macrominerals $(\mathrm{g} / 100 \mathrm{~g})$ present were: $\mathrm{Na}(0.37), \mathrm{K},(0.22), \mathrm{Mg}(0.03)$ and $\mathrm{Ca}(0.01)$, while the microminerals $(\mathrm{mg} / \mathrm{kg})$ present were $\mathrm{Zn}(7.1)$, Fe (10.0), $\mathrm{Cu}$ (0.8), $\mathrm{Pb}(0.09), \mathrm{Cd}(0.08)$ and $\mathrm{Hg}(0.01)$. These results differed slightly from those obtained for raw giant squid arms in our study. Jiao et al. (2018) found that squid from offshore fisheries in the China Sea might pose a higher potential health risk from polluting metals than those from the Pacific and Atlantic oceans, with only a slight difference between the latter two. In the present study, fishery origin does not appear to be a relevant factor as regards the mineral content of the raw material. As can be seen, the levels of semimetals and metals in raw arms were quite homogeneous, despite coming from different fisheries and freezing factories.

Regardless of the raw material used, the mineral content of squid may change during thawing, marination and cooking. Thawing inside a tank with a drainage system may favour mineral leaching, while injection of a water solution containing sodium salts may contribute to holding the juices and dissolved minerals. The injected minerals would be better retained in large size arms as dissolved electrolytes should diffuse to a longer average distance to reach arm external exchange surface, where both mineral 
Table 6: Total intake and per cent covered (in parentheses) of the Daily Recommended Intake (DRI) for selected minerals through the consumption of $100 \mathrm{~g}$ cooked squid arms by an adult consumer weighing $60 \mathrm{~kg}$

\begin{tabular}{|c|c|c|c|c|c|}
\hline & \multicolumn{4}{|c|}{ Cooked squid arms } & \multirow[t]{3}{*}{ DRIs } \\
\hline & Chile & Benthic & Peru & Overall & \\
\hline & M & M & M & M & \\
\hline \multicolumn{6}{|c|}{ Macrominerals (mg) } \\
\hline $\mathrm{Ca}$ & $30(0.3)$ & $30(0.3)$ & $30(0.3)$ & $30(0.3)$ & $1,000 \mathrm{mg}$ \\
\hline $\mathrm{K}$ & $110(2.3)$ & $110(2.3)$ & $90(1.9)$ & $100(2.1)$ & $4,700 \mathrm{mg}$ \\
\hline $\mathrm{Mg}$ & $33(9.4)$ & $49(14.0)$ & $29(8.3)$ & $37(10.6)$ & $350 \mathrm{mg}$ \\
\hline $\mathrm{Na}$ & $330(14.3)$ & $490(21.3)$ & $290(12.6)$ & $370(16.1)$ & $2,300 \mathrm{mg}$ \\
\hline \multicolumn{6}{|c|}{ Microminerals $(\mu \mathrm{g})$} \\
\hline As & $77(2.6)$ & $99(3.3)$ & $68(2.3)$ & $81(2.7)$ & $3,000 \mu \mathrm{g}$ \\
\hline $\mathrm{B}$ & $36(0.2)$ & $47(0.2)$ & $47(0.2)$ & $44(0.2)$ & $20,000 \mu \mathrm{g}$ \\
\hline $\mathrm{Cr}$ & $11(36.7)$ & 7 (23.3) & $6(20.0)$ & $8(26.7)$ & $30 \mu \mathrm{g}$ \\
\hline $\mathrm{Cu}$ & $335(3.4)$ & $313(3.1)$ & $24(2.7)$ & $296(0.2)$ & $10,000 \mu \mathrm{g}$ \\
\hline $\mathrm{Fe}$ & $196(0.4)$ & $415(0.9)$ & $142(0.3)$ & $251(0.6)$ & $45,000 \mu \mathrm{g}$ \\
\hline $\mathrm{Mn}$ & $263(12.8)$ & $316(15.4)$ & $260(12.7)$ & $280(13.7)$ & $2,050 \mu \mathrm{g}$ \\
\hline $\mathrm{Ni}$ & $5(0.5)$ & $2(0.2)$ & $2(0.2)$ & $3(0.3)$ & $1,000 \mu \mathrm{g}$ \\
\hline $\mathrm{Se}$ & 40 (13.3) & $31(10.3)$ & $36(12.0)$ & $36(12.0)$ & $300 \mu \mathrm{g}$ \\
\hline $\mathrm{Zn}$ & 2279 (22.8) & 1944 (19.4) & 2209 (22.1) & $2144(21.4)$ & $10,000 \mu \mathrm{g}$ \\
\hline
\end{tabular}

DRIs published by the Institute of Medicine (United States of America) (2011) except for As (WHO, 1989).

absorption and leaching can take place. Results obtained for $\mathrm{Na}$ are a good indicator of what occurred. The raw arms from the three origins only presented small differences in concentration of $\mathrm{Na}$. Once arms were marinated and cooked, large size arms (i.e. Benthic samples) contained the highest concentration of $\mathrm{Na}$, which was associated to a higher retention of juice. Thus, other minerals present might have followed a similar diffusivity pattern.

For the same reason, the cooking broth may also exchange minerals with the marinated squid. However, the overall increase observed for the mineral content after cooking seems to reflect product dehydration. Juice loss and subsequent mineral concentration are inversely related to fish and shellfish size (Kalogeropoulos et al., 2012). In the present study, squid arms were cooked in a broth containing spices, sodium salts and other ingredients, and cooking time was adjusted to arm size in order to standardize juice loss and prevent overcooking. As seen, the cooked product showed good juice retention (around $75 \mathrm{~g} / 100 \mathrm{~g}$ moisture) in samples from each origin. Cooking losses reported for squid in other studies are even higher. For example, Kalogeropoulos et al. (2012) found moisture contents (g/100g) of 81.4 (raw), 44.0 (pan-fried) and 63.9 (grilled), Czech and Stachyra (2013) found values of 87.1 (raw) and 12.5 (pan-fried), while in another study, Galitsopoulou et al., (2013) noted values of 83.4 (raw), 73.1 (grilled) and 72.6 (canned) in whole squid from California (Loligo opalescens). Therefore, both marination treatment and cooking time need to be adjusted, especially considering giant squid arm may lose around $70 \%$ of its raw weight when cooked in polypropylene bags at $100{ }^{\circ} \mathrm{C}$ for $10 \mathrm{~min}$ (Torres-Arreola et al. 2018). Other studies agree that cooking loss may lead to a concentration of minerals in squid products. Kalogeropoulos et al. (2012) also found increased levels (compared to raw material) of trace metals (Cd, Cr, $\mathrm{Cu}, \mathrm{Fe}, \mathrm{Hg}, \mathrm{Ni}, \mathrm{Pb}$ and $\mathrm{Zn}$ ) in cooked squid flesh, in which values reached $(\mathrm{mg} / \mathrm{kg}) 18(\mathrm{Zn}), 16(\mathrm{Fe}), 7.1(\mathrm{Cu})$, $0.77(\mathrm{Cd}), 0.18(\mathrm{Hg}), 0.13(\mathrm{Cr}), 0.08(\mathrm{Ni})$ and $0.04(\mathrm{~Pb})$. Czech and Stachyra (2013) found similar results in panfried squid for macro- $(\mathrm{Na}, \mathrm{Ca}$ and $\mathrm{Mg}$ ) and microminerals $(\mathrm{Cu}, \mathrm{Fe}$ and $\mathrm{Zn})$. In the above study, sunflower oil and wheat flour also provided minerals to the final product. In contrast, other studies indicated that the cooking process is of very limited value as a means of reducing metal concentrations. Any hypothetical reduction would depend upon cooking conditions (time, temperature, and cooking medium) (Perello et al. 2008). In addition, it is known that cooking procedures may, in certain conditions, change the amount of chemical pollutants in foods (Zabik et al., 1995; Bayen et al., 2005). For instance, it was seen that baked and microwave-cooked fish present higher concentrations of $\mathrm{Na}, \mathrm{K}, \mathrm{Ca}, \mathrm{Mg}$ and $\mathrm{Zn}$ than grilled and fried fish, due to their differences in juice loss (Ersoy and Özeren, 2008). The factors contributing to increasing the mineral concentration of cooked squid arm (mineral absorption and juice loss) predominated over the mineral leaching that occurs during thawing, marination and cooking.

The nutritional implications of shellfish consumption are important, particularly any knowledge concerning the dietary intake of toxic heavy metals (Storelli et al., 2012). The dietary requirement for a micronutrient is defined as an intake level that meets specified criteria related to adequacy, thereby minimizing the risk of nutrient deficit or excess (Dietary Recommended Guide, 2006). Nutritional indexes, such as PRI, TI and UL, are used to estimate the 
DRIs for minerals, although the calculation based on the total content of minerals does not look at other possible factors affecting their bioaccessibility (e.g. denaturation and de-methylation of muscle metalloproteins) (Ouédraogo and Amyot, 2011). As expected, the average consumption of cooked squid arms, a product treated with sodium salts, covered a relevant percentage of the DRI for $\mathrm{Na}$ and $\mathrm{Mg}$ as well as for $\mathrm{Se}, \mathrm{Cu}, \mathrm{Cr}$ and $\mathrm{Zn}$. In contrast, the contribution of other minerals was far below their ULs. Jiao et al. (2018) identified As accumulation as a primarily hazard for human health associated with squid consumption. The present study did not confirm this view, since the concentration of As in cooked squid arms was below maximum limits $(1.0 \mathrm{mg} / \mathrm{kg})$ permitted for fish and shellfish in countries such as Australia, Brazil or South Africa (1.0-3.5 mg/kg) (Gladieux and Swail, 1998). Similarly, the accumulation levels $(\mathrm{mg} / \mathrm{kg}$ ) found for toxic heavy metals were far below the ULs established for $\mathrm{Hg}(0.5), \mathrm{Cd}(1.0)$ and $\mathrm{Pb}(0.3)$ (European Commission "EC" Regulations 1881/2006 of and 629/2008). As a consequence, the estimated EWIs and their corresponding PTWIs for the consumption of cooked squid were well below recommendations established by health organizations for $\mathrm{Hg}, \mathrm{Cd}$ and $\mathrm{Pb}$ (WHO, 2003; EFSA, 2011). Other studies on shellfish and fish products reported slightly higher EWIs and PTWIs for toxic metals (Storelli, 2008; Pastorelli et al., 2012), while Kalogeropoulos et al. (2012) estimated EWIs as 0.21-0.23 (Hg), 0.03-0.05 $(\mathrm{Pb}), 0.56-0.88(\mathrm{Cd})$ in cooked squid flesh. The levels of minerals found in the marinated-cooked giant squid arms indicate that as regards polluting metals, these can be consumed with a wide margin of safety.

\section{CONCLUSIONS}

Giant squid from the Eastern Pacific Ocean provide a raw material of high nutritional quality, containing a large number of essential macro- and microminerals. Raw squid arms were seen to have quite homogeneous content in terms of semimetals and metals despite proceeding from fisheries distant from each other and being obtained from different freezing factories located in Peru, Chile and China. The low amounts of toxic metals in the raw materials suggest that these Pacific fisheries are not currently seriously affected by human polluting activities' From a technological point of view, fishery origin, which may lead to great differences in squid size, modulates the retention of juices and $\mathrm{Na}$ by squid arms, that came from the marination salt and cooking broth used. Marination and cooking treatments had little influence on levels of $\mathrm{Pb}, \mathrm{Hg}$, Zn or As in squid arms, despite there being certain mineral concentration due to juice losses by cooking. The levels of $\mathrm{Pb}, \mathrm{Hg}, \mathrm{Zn}$ or As found in the ready-to-eat product were below the tolerable upper intake levels. According the DRIs calculated for the minerals, marinated-cooked Pacific squid arms provide a part of mineral requirements in the human diet and can be consumed without apparent negative nutritional implications.

\section{Author contributions}

Conceptualization, F.F. and S.B.; methodology (industrial plant and laboratory), F.F. and C.L.; data analysis and validation, F.F. and S.B.; investigation, F.F., C.L. and S.B.; resources, S.B.; writing-original draft preparation, F.F. and S.B.; writing-review and editing, S.B.; supervision, S.B. (F.F: Faustina Fernández; C.L. Celia Lucas; and S.B. Sancho Bañón).

\section{REFERENCES}

Agusa, T., T. Kunito, A. Sudaryanto, I. Monirith, S. Kan-Atireklap, H. Iwata, A. Ismail, J. Sanguansin, M. Muchcar, T.S. Tana and S. Tanabe. 2007. Exposure assessment for trace elements from consumption of marine fish in Southeast Asia. Environ. Pollut. 145: 766-777.

Ayas, Z., G. Ekmekci, S. V. Yerli and M. Ozmen. 2007. Heavy metal accumulation in water, sediments and fishes of Nallihan Bird Paradise, Turkey. J. Environ. Biol. 28: 545-549.

Azlan, A., M. Izuan, E. Halmi, M. Radyaqsa and U. N. Makassar. 2012. Heavy metals (mercury, arsenic, cadmium, plumbum) in selected marine fish and shellfish along the Straits of Malacca. Int. Food Res. J. 19: 135-140.

Bayen, S., P. Barlow, H. K. Lee, and J. P. Obbard. 2005. Effect of cooking on the loss of persistent organic pollutants from salmon. J. Toxicol. Environ. Health Part A. 68: 253-265.

Carvalho, M. L., S. Santiago and M. L. Nunes. 2005. Assessment of the essential element and heavy metal content of edible fish muscle. Anal. Bioanal. Chem. 382: 426-432.

Castro-González, M. I. and M. Méndez-Armenta. 2008. Heavy metals: Implications associated to fish consumption. Environ. Toxicol. Pharmacol. 26: 263-271.

Catsiki, V. A. and E. Strogyloudi. 1999. Survey of metal levels in common fish species from Greek waters. Sci. Total Environ. 237: 387-400.

Czech., A. K. and Stachyra. 2013. Effect of processing treatments (frozen, frying) on contents of minerals in tissues of "frutti di mare." Int. J. Food Sci. Tech. 48: 238-245.

Domingo, J. L., A. Bocio, R. Martí-Cid and J. M. Llobet. 2006. Benefits and risks of fish consumption. Toxicol. 230(2-3): 227-233.

Duysak, Ö. and E. Uğurlu. 2017. Metal accumulations in different tissues of cuttlefish (Sepia officinalis L., 1758) in the Eastern Mediterranean coasts of Turkey. Environ. Sci. Pollut. Res. 24: 9614-9623.

Ersoy, B. and A. Özeren. 2009. The effect of cooking methods on mineral and vitamin contents of African catfish. Food Chem. 115: 419-422.

European Commission. 2006. EC Regulation No 1881/2006 of 19 December 2006 Setting Maximum Levels for Certain Contaminants in Foodstuffs. OJEU L. 364: 5-24.

European Commission. 2008. EC Regulation No 629/2008 of 2 July 2008 Setting Maximum Levels for Certain Contaminants in Foodstuffs. OJEU L. 173: 6-9.

European Food Safety Authority. 2006. Tolerable Upper Intake Levels for Vitamins and Minerals. Available from: https://www. 
efsa.europa.eu/sites/default/files/efsa_rep/blobserver_assets/ ndatolerableuil.pdf.

European Food Safety Authority. 2017. Overview on Dietary Reference Values for the EU Population as Derived by the EFSA Panel on Dietetic Products, Nutrition and Allergies. Available from: https:// www.efsa.europa.eu/sites/default/files/assets/DRV_Summary_ tables_jan_17.pdf.

European Food Safety Authority. 2010. Scientific Opinion on Lead in Food. Lead, occurrence, dietary exposure, food consumption, risk assessment, adults, children, margin of exposure. EFSA J. 8: 1570. Available from: https://www.efsa.europa.eu/en/ efsajournal/pub/1570.

European Food Safety Authority. 2011. Scientific Opinion. Statement on Tolerable Weekly Intake for Cadmium. Available from: http:// www.efsa.europa.eu/en/efsajournal/doc/1975.pdf.

Förstner, U. and G. T. W. Whittmann. 1981. Metal Pollution in the Aquatic Environment. 2nd Edition. Springer-Verlag, Berlin, 486. (Vol. 84). from http://ir.obihiro.ac.jp/dspace/handle/10322/3933

Galitsopoulou, A., D. Georgantelis and M. G. Kontominas. 2013. Effect of thermal processing and canning on cadmium and lead levels in California market squid: The role of metallothioneins. Food Addit. Contam. Part A Chem. Anal. Control. Expo. Risk Assess. 30: 1900-1908.

Gladieux, L. and W. Swail. 1998. Postsecondary Education: Student Success, not just Access. The Forgotten Half, p. 101-114. Available from: http://www.scholar.google.com/scholar?q=Gladi eux+Swail\&btnG=\&hl=en\&as_sdt $=0 \% 2 \mathrm{C} 6 \# 4$.

International Standards Organization. 2018. Meat and Meat Products. Determination of Nitrogen Content. Available from: https://www. iso.org/standard/5356.html.

ISO 1442:1997. 2018. Meat and Meat Products. Determination of Moisture Content. Available from: https://www.iso.org/ standard/6037.html.

ISO Norm 1443:1973. 2016. Meat and Meat Products. Determination of Total Fat Content. Available from: https://www.iso.org/ standard/6038.html.

International Standards Organization (ISO) 11885:2007. 2016. Water Quality. Determination of Selected Elements by Inductively Coupled Plasma Optical Emission Spectrometry (ICP-OES). Available from: https://www.iso.org/standard/36250.html.

Jaishankar, M., T. Tseten, N. Anbalagan, B. B. Mathew and K. N. Beeregowda. 2014. Toxicity, mechanism and health effects of some heavy metals. Interdiscip. Toxicol. 7: 60-72.

Jiao, Y., J. Chen, W. Li, Y. Liu, C. Xin and L. Yang. 2018. Trace elements concentrations in squids consumed in Shandong Province China and their associated risks to the human health. Mar. Pollut. Bull. 128: 267-274.

Kalogeropoulos, N., S. Karavoltsos, A. Sakellari, S. Avramidou, M. Dassenakis and M. Scoullos. 2012. Heavy metals in raw, fried and grilled Mediterranean finfish and shellfish. Food Chem. Toxicol. 50: 3702-3708.

Kilgour, B. W. 1991. Cadmium uptake from cadmium-spiked sediments by four freshwater invertebrates. Bull. Environ. Contam. Toxicol. 47: $70-75$

Leblanc, J. C., T. Guérin, L. Noël, G. Calamassi-Tran, J. L. Volatier and P. Verger. 2005. Dietary exposure estimates of 18 elements from the $1^{\text {st }}$ French Total Diet Study. Food Addit. Contam. 22: 624-641.
Llobet, J. M., G. Falcó, C. Casas, A. Teixidó and J. L. Domingo. 2003. Concentrations of arsenic, cadmium, mercury, and lead in common foods and estimated daily intake by children, adolescents, adults, and seniors of Catalonia, Spain. J. Agri. Food Chem. 51: 838-842.

Mendil, D. and Ö. D. Uluözlü. 2007. Determination of trace metal levels in sediment and five fish species from lakes in Tokat, Turkey. Food Chemistry, 101: 739-745.

Ouédraogo, O. and M. Amyot. 2011. Effects of various cooking methods and food components on bioaccessibility of mercury from fish. Environ. Res. 111: 1064-1069.

Pastorelli, A. A., M. Baldini, P. Stacchini, G. Baldini, S. Morelli, E. Sagratella, S. Zaza and S. Ciardullo. 2012. Human exposure to lead, cadmium and mercury through fish and seafood product consumption in Italy: A pilot evaluation. Food Addit. Contam. Part A Chem. Anal. Control. Expo. Risk Assess. 29: 1913-1921.

Perello, G., R. Martí-Cid, J. M. Llobet and J. L. Domingo. 2008. Effects of various cooking processes on the concentrations of arsenic, cadmium, mercury, and lead in foods. J. Agri. Food Chem. 56: 11262-11269.

Smith, A. H., E. O. Lingas and M. Rahman. 2000. Contamination of Drinking Water by Arsenic in Bangladesh : A Public Health Emergency. Contamination of Drinking-water by Arsenic in Bangladesh: A Public Health Emergency. World Health Organization, Geneva, Switzerland, p. 1093.

Storelli, M. M. 2008. Potential human health risks from metals $(\mathrm{Hg}$, $\mathrm{Cd}$, and $\mathrm{Pb}$ ) and polychlorinated biphenyls (PCBs) via seafood consumption: Estimation of target hazard quotients (THQs) and toxic equivalents (TEQs). Food Chem. Toxicol. 46: 2782-2788.

Storelli, M. M., G. Barone and G. O. Marcotrigiano. 2005. Cadmium in cephalopod molluscs: Implications for public health. Journal of Food Protection, 68: 577-580.

Storelli, M. M., G. Normanno, G. Barone, A. Dambrosio, L. Errico, R. Garofalo and R. Giacominelli-Stuffler. 2012. Toxic metals (Hg, $\mathrm{Cd}$, and $\mathrm{Pb}$ ) in fishery products imported into Italy: Suitability for human consumption. J. Food Protec. 75: 189-194.

Torres-Arreola, W., V. M. Ocaño-Higuera, J. M. Ezquerra-Brauer, B. E. López-Corona, F. Rodríguez-Felix, R. Castro-Longoria and H. E. Ramírez-Guerra. 2018. Effect of cooking on physicochemical and structural properties of jumbo squid (Dosidicus gigas) muscle. J. Food Process. Preserv. 42: 1-8.

Vilizzi, L. and A. S. Tarkan. 2016. Bioaccumulation of metals in common carp (Cyprinus carpio L.) from water bodies of Anatolia (Turkey): A review with implications for fisheries and human food consumption. Environ. Monit. Assess., 188: 243.

WHO. 2003. Summary and Conclusions of the $61^{\text {st }}$ Meeting of the Joint FAO/WHO Expert Committee on Food Additives JECFA/61/ sc. World Health Organization, Rome, Italy.

Younis, A. M., H. F. Amin, A. Alkaladi and Y. Y. I. Mosleh. 2015 Bioaccumulation of heavy metals in fish, squids and crustaceans from the red sea, Jeddah coast, Saudi Arabia. Open J. Mar. Sci. 5: 369-378.

Zabik, M. E., M. J. Zabik, A. M. Booren, S. Daubenmire, M. A. Pascall, R. Welch and H. Humphrey. 1995. Pesticides and total polychlorinated biphenyls residues in raw and cooked walleye and white bass harvested from the great lakes. Bull. Environ. Contam. Toxicol. 54: 396-402. 